\title{
Maize Response to Blended Fertilizer Estimates through Nutrient Use Efficiency and Economic Analysis from Assosa, Western Ethiopia
}

Bakala Anbessa Fayisa ( $\sim$ anbessa2004@gmail.com )

Ethiopian Institute of Agricultural Research https://orcid.org/0000-0001-5253-7828

Girma Abera Jibat

Ministry of Higher Education

Sofiya Kasa Abdella

Ethiopian Institute of Agricultural Research

\section{Research}

Keywords: blende fertilizer, rate, yield, yield components, nutrient use efficiency, net benefit, marginal rate return

Posted Date: August 13th, 2021

DOl: https://doi.org/10.21203/rs.3.rs-768854/v1

License: (-) (i) This work is licensed under a Creative Commons Attribution 4.0 International License. Read Full License 


\section{Abstract}

Context: Soil fertility depletion and soil acidity are critical problems for maize (Zea mays L) production in western Ethiopia.

Objective: Therefore, a field experiment was conducted on Nitisols of Assosa Agricultural Research Centre during 2016 to2017 cropping season to investigate the response of growth, yield and nutrient use efficiency of maize (Zea mays L.) to different blended fertilizer rates and types.

Methods: The treatments consists of: control, three rates of $\mathrm{N}$ and $\mathrm{P}$ combined $\left(92 / 46,115 / 57\right.$ and $138 / 69 \mathrm{~N} / \mathrm{P}_{2} \mathrm{O}_{5} \mathrm{~kg} \mathrm{ha}^{-1}$ and two formula of blended fertilizers with different rates, formula 2 consists of $100 \mathrm{~kg} \mathrm{NPSB}+73.9 \mathrm{~N}, 150 \mathrm{~kg} \mathrm{NPSB}+110.8 \mathrm{~N}$ and $200 \mathrm{~kg} \mathrm{NPSB}+147.8 \mathrm{~N} \mathrm{~kg} \mathrm{ha}^{-1}$ and formula 4 consists of $100 \mathrm{~kg} \mathrm{NPSZnB}+75.1 \mathrm{~N}, 150 \mathrm{~kg} \mathrm{NPSZnB}+112.6 \mathrm{~N}^{1}$ and $200 \mathrm{~kg}$ NPSZnB $+150.2 \mathrm{~N} \mathrm{~kg} \mathrm{ha}^{-1}$. The treatments were laid out as a Randomized Complete Block Design with three replications.

Result and and conclusion: Application of blended fertilizers (NPSB, NPSZnB) hastened days to tasseling silking and maturity by 10,7 and 15 days, respectively as compared to combined $N$ and $P$ rates. Application of blended fertilizer increases significantly ( $p \leq 0.01$ ) the plant height, cob weight, ear length, 100 kernels weight, number of kernels per row and ear height as compared to combined $\mathrm{N}$ and $\mathrm{P}$ and the control. The analysis of variance revealed that fertilizer types and rates significantly $(P \leq 0.01)$ affected on grain yield, straw yield and harvest index. However there was no significant difference between the two blended fertilizer types. Maximum grain yield $\left(7056.2 \mathrm{~kg} \mathrm{ha}^{-1}\right.$ ) was recorded with $200 \mathrm{Kg} \mathrm{NPSZnB}+150.2 \mathrm{~N} \mathrm{~kg} \mathrm{ha}^{-1}$ application, while minimum grain yield $2996.0 \mathrm{~kg} \mathrm{ha}^{-1}$ was recorded from control treatment. The application of $150 \mathrm{~kg} \mathrm{NPSB}+110.8 \mathrm{~N} \mathrm{~kg} \mathrm{ha}^{-}$ ${ }^{1}$ had highest Marginal rate of return (MRR\%) and net benefit.

Significance: Therefore, we recommended the treatment (150 Kg NPSB $\left.+110.8 \mathrm{~N} \mathrm{~kg} \mathrm{ha}^{-1}\right)$ since it produced high marginal rate of return, high net benefit and relatively small total cost of production, for maize production in Asossa area. Furthermore, based on yield, net benefit and relatively low total cost of production the farmer of Asossa area also can use $150 \mathrm{~kg} \mathrm{NPSZnB}+112.6 \mathrm{~N}$ in case of absence of NPSB in market.

\section{Introduction}

Among cereals, maize (Zea mays L.) ranks third after wheat and rice in the world ${ }^{1}$. It is one of the most important cereal crops used for human diet in large parts of the world, besides served as important feed component for livestock. In terms of total world production, maize out ranked paddy rice and wheat (Rasheed et al., 2004).

Cereals are the primary food crops in Ethiopia covering $79.88 \%$ (9,974,316 hectares) of total crop lands, while maize covered $16.91 \%$ (about 2, 111,518 hectares) of land allocated for cereal and gave 7,150,835.4 tons of grain yield (CAS 2015/2016). Despite the large area under maize, the national average yield of maize is about $3.387 \mathrm{t} \mathrm{ha}^{-1}$. This is by far lower than the world's average yield which is about $5.21 \mathrm{tha}^{-1}$ and also lower than the average national research center based yields $\left(8 \mathrm{tha} \mathrm{h}^{-1}\right)$ in Ethiopia (Hagos et al., 2016). These are attributed to many factors: lack of access to seeds of improved varieties, poor soil fertility, and diseases and insect pests.

Low soil fertility is one of the bottlenecks to sustain agricultural production and productivity in Ethiopia. The problem is aggravated by several factors which include among others, soil erosion, nutrient mining, soil acidity and low level of application of nitrogen and phosphorus. Furthermore, unbalanced application of plant nutrients may aggravate the depletion of other important nutrient elements in soils such as K, Mg, Ca, S and micro-nutrients (Getachew 2013). Thus, maize is one of the heaviest feeder of nutrients to produce high and quality yields among cereals. This is because of the fact that it produces higher grain and straw yields than other cereals. Hence application of balanced fertilizers is the basis to produce more crop output from

the existing land under cultivation as nutrient needs of crops is according to their physiological requirements and expected yields (Ryan 2008). Most of the fertilizer experiment in Ethiopia focus on $N$ and $P$ requirements of crops, hence limited information is available on various sources of nutrients such as K, S, Zn and B and other micronutrients. However, recently blended fertilizers were introduced to Ethiopia to combat the limitations of various essential nutrients in crop production. Therefore, it is paramount 
important to assess maize response towards different blended fertilizers such as NPSB and NPSZnB, besides the conventional fertilizers $\mathrm{N}$ and $\mathrm{P}$ fertilizers application.

Nutrient use efficiency is the ability of a plant to utilize soil available nutrients to result in measurable yield or yield parameters such as plant height, leaf development, dry matter and fruit grain production (Hati et al., 2006). Partial factor productivity (PFP), agronomic efficiency (AE), uptake efficiency (RE), physiological efficiency (PE) and internal utilization efficiency (IE) constitute a set of simple indices and could be used in agronomic research to appraise the applied fertilizer efficiency particularly to assess the short-term response of crop to a nutrient(Dobermann 2005). The 'difference method' (calculation of nutrient use efficiencies using differences in crop yield and/or nutrient uptake between fertilized plots and an unfertilized control) is cost-efficient and simple making it particularly suitable for on-farm research (Dobermann 2005). However, there is a lack of scientific studies to examine the effect of blended fertilizer in improving the yield and nutrient uptake efficiency of maize in Asossa District. The amounts of nutrients exploited in the harvested portion of the crop will depend on the yield and the concentration of the nutrients in time and space, variety, soil and environmental factors (Fageria, 2011). To use fertilizer in a sustainable manner, management practices must aim at maximizing the amount of nutrients that are taken up by the crop and minimizing the amount of nutrients that are lost from the soil (Bationo et al., 2012). Therefore this experiment was designed to assess the role of blended and conventional fertilizer effects on yield, economic importance and nutrient use efficiency of maize at Asossa district

\section{Materials And Methods Description of the Study Sites}

The experiment was conducted at Assosa Agricultural Research Center (AsARC) in Benishangul Gumuz Regional State, in $2016 / 17$ main cropping season under rain fed field condition. The region is located between $9^{\circ} 30^{\prime}$ to $11^{\circ} 39^{\prime \prime} \mathrm{N}$ latitude and $34^{\circ} 20^{\prime}$ to $36^{\circ} 30^{\prime \prime} \mathrm{E}$ longitude covering a total land area of 50,000 square kilometer. The study site is located at $10^{\circ} 02^{\prime} 05^{\prime \prime} \mathrm{N}$ latitude and $34^{\circ} 34^{\prime} 09^{\prime \prime} \mathrm{E}$ longitudes. The study area is situated east of Assosa town and west of Addis Ababa about $4 \mathrm{~km}$ and $660 \mathrm{~km}$ distance, respectively. Assosa has unimodal rainfall pattern, which starts at the end of April and extends to mid-November, with maximum rainfall amount received in June to October. The total annual average rainfall of Assosa is $1275 \mathrm{~mm}$. The minimum and maximum temperatures are $16.75^{\circ} \mathrm{C}$ and $27.92^{\circ} \mathrm{C}$, respectively. The dominant soil type of Assosa area is Nitosols with the soil $\mathrm{pH}$ ranges from 5.0 to 6.0 .

\section{Experimental Design and Treatments}

The experiment was laid out in randomized complete block design with three replications. Hybrid maize variety (BH546) was used as test crop. The treatments included control, three rates of nitrogen and phosphorus $\left(92 \mathrm{~N}+46 \mathrm{P}_{2} \mathrm{O}_{5}, 115 \mathrm{~N}+57.5 \mathrm{P}_{2} \mathrm{O}_{5}, 138\right.$ $\mathrm{N}+69 \mathrm{P}_{2} \mathrm{O}_{5} \mathrm{~kg} \mathrm{ha}^{-1}$ ) and two different formula of blended fertilizers each with three rates, $100 \mathrm{~kg} \mathrm{NPSB}+73.9 \mathrm{~N}{ }^{1}, 150 \mathrm{~kg} \mathrm{NPSB}$ $+110.8 \mathrm{~N}$ and $200 \mathrm{~kg} \mathrm{NPSB}+147.8 \mathrm{~N} \mathrm{~kg} \mathrm{ha}{ }^{-1}$, and $100 \mathrm{~kg} \mathrm{NPSZnB}+75.1 \mathrm{~N}, 150 \mathrm{~kg} \mathrm{NPSZnB}+112.6 \mathrm{~N}^{1}$ and $200 \mathrm{~kg} \mathrm{NPSZnB}+$ $150.2 \mathrm{~N} \mathrm{~kg} \mathrm{ha}^{-1}$ ) based on soil fertility map of the region. Blended fertilizers and TSP were basal applied at planting and Urea was top dressed twice (at knee height and tasseling). The plot size of $4.5 \mathrm{~m} \times 5.1 \mathrm{~m}\left(22.95 \mathrm{~m}^{2}\right)$ was used. The crop was planted in rows with recommended spacing $(75 \times 30 \mathrm{~cm})$. Other field management practices were applied uniformly for all plots as per the recommendation for the crop.

Fertilizer treatments based on recommended $\mathrm{N}$ and $\mathrm{P}$, and blended fertilizer types and 


\begin{tabular}{|c|c|c|}
\hline Trt.No & Rate $\left(\mathrm{kgha}^{-1}\right)$ & Blended fertilizers' mineral contents (\%) \\
\hline T1 & Control( no fertilizer) & 0 \\
\hline $\mathrm{T} 2$ & $200 \mathrm{~kg}$ Urea + $100 \mathrm{~kg}$ TSP & $92 \mathrm{~N} \& 46 \mathrm{P}_{2} \mathrm{O}_{5}$ \\
\hline T3 & $250 \mathrm{~kg}$ Urea + $125 \mathrm{~kg}$ TSP & $115 \mathrm{~N} \& 57.5 \mathrm{P}_{2} \mathrm{O}_{5}$ \\
\hline $\mathrm{T} 4$ & $300 \mathrm{~kg}$ Urea + $150 \mathrm{~kg}$ TSP & $138 \mathrm{~N} \& 69 \mathrm{P}_{2} \mathrm{O}_{5}$ \\
\hline T5 & $100 \mathrm{~kg} \mathrm{NPSB}+73.9 \mathrm{~N}$ & $18.1 \mathrm{~N}-36.1 \mathrm{P}_{2} \mathrm{O}_{5}-0.0 \mathrm{~K}_{2} \mathrm{O}+6.7 \mathrm{~S}+0.0 \mathrm{Zn}+0.71 \mathrm{~B}$ \\
\hline T6 & $150 \mathrm{~kg} \mathrm{NPSB}+110.8 \mathrm{~N}$ & $27.15 \mathrm{~N}-54.15 \mathrm{P}_{2} \mathrm{O}_{5}-0.0 \mathrm{k}_{2} \mathrm{O}+10.05 \mathrm{~S}+0 \mathrm{Zn}+1.07 \mathrm{~B}$ \\
\hline T7 & $200 \mathrm{~kg}$ NPSB $+147.8 \mathrm{~N}$ & $36.2 \mathrm{~N}-72.2 \mathrm{P}_{2} \mathrm{O}_{5}-0.0 \mathrm{k}_{2} \mathrm{O}+13.4 \mathrm{~S}+\mathrm{Zn}+1.42 \mathrm{~B}$ \\
\hline T8 & $100 \mathrm{~kg} \mathrm{NPSZnB}+75.1 \mathrm{~N}$ & $16.9 \mathrm{~N}-33.8 \mathrm{P}_{2} \mathrm{O}_{5}-0.0 \mathrm{k}_{2} \mathrm{O}+7.3 \mathrm{~S}+2.23 \mathrm{Zn}+0.67 \mathrm{~B}$ \\
\hline T9 & 150 kg NPSZnB + 112.6 N & $25.35 \mathrm{~N}-50.7 \mathrm{P}_{2} \mathrm{O}_{5}-0.0 \mathrm{k}_{2} \mathrm{O}+10.95 \mathrm{~S}+3.35 \mathrm{Zn}+1.01 \mathrm{~B}$ \\
\hline T10 & $200 \mathrm{~kg}$ NPSZnB $+150.2 \mathrm{~N}$ & $33.8 \mathrm{~N}-67.6 \mathrm{P}_{2} \mathrm{O}_{5}-0.0 \mathrm{k}_{2} \mathrm{O}+14.6 \mathrm{~S}+4.46 \mathrm{Zn}+1.34 \mathrm{~B}$ \\
\hline
\end{tabular}

\section{Plant Tissue Sampling and Analysis}

Representative grain and straw samples were taken from each plot at crop physiological maturity. The samples were oven dried and ground for laboratory analysis of total N, P, S and K. The measurement of N was carried out according to the Kjeldahl procedure by transforming organic $\mathrm{N}$ into ammonium $\mathrm{N}$ by digesting with $\mathrm{H}_{2} \mathrm{SO}_{4}$ and a catalyst (Chapman 1965). Potassiumwas measured using dry ashing, by flame Photometer as described by (Chapman 1965).Phosphorus was determined by spectrophotometer using the dry ash of maize samples. Total Swas analyzed using Calorimeter. The grain and straw concentrations of $\mathrm{N}, \mathrm{P}, \mathrm{S}$ and $\mathrm{K}$ were used to estimate the uptake of representative elements which was calculated by multiplying grain and straw yields on hectare basis with the respective $\mathrm{N}, \mathrm{P}, \mathrm{S}$ and $\mathrm{K}$ concentration.

Apparent fertilizer $\mathrm{N}$ and $\mathrm{P}$ recovery were calculated following the formula as:

AP = (TU fertilized treatment $-\mathrm{TU}$ control $) \times 100 ;$

Amount of nutrient applied kg/ha

Where AP = Apparent recovery, TU stands for total nutrient uptake at ' $n$ ' rate of fertilizer nutrient.

A Physiological efficiency is the yield obtained per unit of nutrient uptake (Fageria, 2009)

Physiological efficiency $=$ grain yield of fertilized $\mathrm{kg} / \mathrm{ha}$ - grain yield unfertilized $\mathrm{kg} / \mathrm{ha}$

Nutrient uptake of fertilized in kg- Nutrient uptake of control in $\mathrm{kg}$

Agronomic efficiency = grain yield of fertilized kg/ha - grain yield unfertilized kg/ha

Amount of fertilizer applied ( $\mathrm{kg} / \mathrm{ha})$

\section{Partial budget Analysis}

Economic analysis was performed to investigate feasibility of fertilizer application for maize production in Assosa district (CIMMYT 1998). Mean grain yield of maize was used for the study. A partial budget, dominance and marginal analysis were used. The average open market price (Birr kg ${ }^{-1}$ ) for maize and the official prices of blended, Urea and TSP fertilizers were used for economic analysis. The dominance analysis procedure as detailed in (CIMMYT 1998) was used to select potentially profitable treatments from the ranges that were tested. The selected and discarded treatments using this technique are referred 
to as undominated and dominated' treatments, respectively. The undominated treatments were ranked from the lowest (the farmers' practice) to the highest cost treatment. For each pair of ranked treatments, percentage marginal rate of return (MRR) was calculated. The MRR between any pair of undominated treatments denotes the return per unit of investment in fertilizer and expressed as a percentage.

\section{Statistical Analysis}

Analyses of variances for the recorded data were conducted using SAS GLM procedure (SAS, 1998). Least significant difference (LSD) test at $5 \%$ probability was used for mean separation when the analyses of variance indicate the presence of significant difference.

\section{Result And Discussion}

\section{Effects of blended fertilizer rates and types on phonological, growth and yield components of maize.}

Days to $50 \%$ silking, tasseling, maturity, Ear height, Plant height, Ear length, 100 kernels weight and Number of kernels per row except Number of kernel row per cob were highly significantly $(P \leq 0.01)$ affected by application of fertilizer types and rates (Table 1). Early silking, tasseling and maturity were recorded from plots which received blended fertilizers followed by recommended $\mathrm{N}$ and $\mathrm{P}$. On the other hand the longest days to $50 \%$ silking, tasseling and maturity were recorded from the control (without fertilizer applied). This result is in agreement with the finding of (Dagne ,2016), who indicated early tasseling, silking and maturity days were recorded with the application of blended fertilizer and the longest days to $50 \%$ tasseling, silking and maturity were recorded for control (without fertilizers). This result indicated that the fertilizer blend in different proportion of N, P, S Zn and $\mathrm{B}$ might have encouraged early establishment, rapid growth and development of crop thus shorten the day to tasseling silking and heading. Application of blended fertilizers hastened days to tasseling silking and maturity by 10,7 and 15 days, respectively as compared to recommended nitrogen and phosphorous. This could be attributed to the positive interaction of $\mathrm{S}, \mathrm{B}$ and $\mathrm{Zn}$ in the blended fertilizers, which agreed with the finding of Fageria et al., 2002) who reported positive relations between $B, K$ and $N$ fertilizers for improving crop yields and maturity.

Application of treatments had increased the plant height and ear height as compared to recommended $\mathrm{N}$ and $\mathrm{P}$ and the control. This plant height increment might be the cell elongation and vegetative growth that attributed to different nutrient (N, P, S, B and $\mathrm{Zn})$ contents in blended fertilizers. The highest plant height $(245.67 \mathrm{~cm})$ and ear height $(113.67 \mathrm{~cm})$ were recorded under the applications of $200 \mathrm{~kg}$ of F4 (T10), while the least plant height $(186.13 \mathrm{~cm})$ and ear height $(72.33 \mathrm{~cm})$ were recorded from plot that received the control plants. In conformity with the results obtained from this study, Plant growth and development may be retarded significantly if any of nutrient elements is less than its threshold value in the soil or not adequately balanced with other nutrient elements (Landon, 1991).

Similarly application of treatments had increased the ear length, 100 kernels weight, number of kernels per row as compared to recommended $\mathrm{N}$ and $\mathrm{P}$ and the control. Blended fertilizer rates and types had highly significant $(\mathrm{P} \leq 0.01)$ effects on ear length of maize (Table 1). However, there were no significant differences between the two formula types. Blended fertilizer which contains B improved cob weight. This results agree with the finding of Mozafar (1989), who reported that application of B fertilizer to maize production encourage good cob development. The largest ear length $(16.10 \mathrm{~cm})$ was obtained under the application of $200 \mathrm{~kg} \mathrm{NPSZnB}+150.2 \mathrm{~N}$ (T10), while the shortest ear length of maize $(11.57 \mathrm{~cm})$ was recorded under the control. The two types of blended fertilizer formulas (NPSZnB and NPSB) gave similar response to these parameters. Comparing the 100 kernels weight showed that $150 \mathrm{~kg} \mathrm{NPSZnB}+112.6 \mathrm{~N} \mathrm{~kg} \mathrm{ha}^{-1}$ application resulted in $20.05 \%$ and $15.15 \%$ more 100 kernels weight as compared to the control treatment and recommended $\mathrm{N}$ and $\mathrm{P}$ respectively (Table 1 ). Both blended fertilizer types (NPSZnB and NPSZnB) gave more response to number of kernels per row than recommended $\mathrm{N}$ and $\mathrm{P}$, and the control. The maximum number of kernels per row (37.10) was obtained under application of (T10), while minimum number of kernels per row (24.23) was recorded under the control plants. 
The analyzed data of number of kernel row per cob indicated that non-significant difference was observed among fertilizer rates tasted. Application of blended fertilizer T10 increases the number of kernels per row by $53.11 \%$ over the control plot. As compared to the recommended $\mathrm{N}$ and $\mathrm{P}$, the mean value of number of kernels per row increased by $20.84 \%$ for $\mathrm{T} 10$. The highest ear length, 100 kernels weight and number of kernels per row observed under blended fertilizer could be due to the combined effect of nutrients like N, P, S, Zn and B in blended fertilizer which might have enhanced growth and development of crop as compared to the recommended $\mathrm{N}$ and $\mathrm{P}$ and control or without fertilizer. Data regarding to the number of kernel row per cob for various treatments are indicated (Table 1). The mean value and analysis of variance of treatment on number of kernels per row revealed non-significant $(P \geq 0.05)$ difference among fertilizer rates and types. The maximum number of kernel row per cob (15.43) was obtained under application T8 $(100 \mathrm{~kg} \mathrm{NPSZnB}+75.1 \mathrm{~N})$, while this treatment was at par with all other treatments.

Table 1

Mean of days to $50 \%$ silking, tasseling and maturity of maize as influenced by blended fertilizer types and rates at Asossa district.

\begin{tabular}{|c|c|c|c|c|c|c|c|c|c|}
\hline $\begin{array}{l}\text { Treatments } \\
\text { (Nutrients } \\
\mathrm{ha}^{-1} \text { ) }\end{array}$ & $\begin{array}{l}\text { Days to } \\
\mathbf{5 0 \%} \\
\text { tasseling }\end{array}$ & $\begin{array}{l}\text { Days } \\
\text { to } 50 \% \\
\text { Silking }\end{array}$ & $\begin{array}{l}\text { Days to } \\
\mathbf{5 0 \%} \\
\text { maturity }\end{array}$ & $\begin{array}{l}\text { Ear } \\
\text { height(cm) }\end{array}$ & $\begin{array}{l}\text { Plant } \\
\text { height(cm) }\end{array}$ & $\begin{array}{l}\text { Ear } \\
\text { length(cm) }\end{array}$ & $\begin{array}{l}100 \\
\text { kernels } \\
\text { weight(g) }\end{array}$ & $\begin{array}{l}\text { Number } \\
\text { of } \\
\text { kernels } \\
\text { per row }\end{array}$ & $\begin{array}{l}\text { Number } \\
\text { of } \\
\text { kernel } \\
\text { row per } \\
\text { cob }\end{array}$ \\
\hline T1 & $78.66^{a}$ & $88.66^{a}$ & $146.66^{a}$ & $72.33^{c}$ & $186.13^{e}$ & $11.57 \mathrm{e}$ & $40.69^{d}$ & $24.23^{d}$ & 14.6 \\
\hline T2 & $72.00^{b}$ & $82.00^{\mathrm{b}}$ & $140.00^{b}$ & $80.33^{c}$ & $201.50^{\text {bcde }}$ & $14.13^{\mathrm{abcd}}$ & $42.42^{c d}$ & $30.70^{b c}$ & 14.6 \\
\hline T3 & $72.00^{b}$ & $82.00^{\mathrm{b}}$ & $140.00^{b}$ & $80.17^{c}$ & $188.00^{\text {de }}$ & $13.07^{\text {cde }}$ & $40.83^{d}$ & $30.50^{b c}$ & 14.5 \\
\hline T4 & $72.00^{\mathrm{b}}$ & $82.00^{\mathrm{b}}$ & $140.00^{\mathrm{b}}$ & $76.33^{c}$ & $199.83^{\text {cde }}$ & $12.100^{\mathrm{de}}$ & $42.92^{\mathrm{cd}}$ & $29.10^{\mathrm{cd}}$ & 14.9 \\
\hline T5 & $62.00^{c}$ & $72.00^{c}$ & $125.00^{c}$ & $100.67^{\mathrm{ab}}$ & $235.17^{a}$ & $14.47^{\mathrm{abc}}$ & $46.60^{\mathrm{abc}}$ & $34.63^{\mathrm{ab}}$ & 15.1 \\
\hline T6 & $62.00^{c}$ & $72.00^{c}$ & $125.00^{c}$ & $101.83^{\mathrm{ab}}$ & $232.67^{a b}$ & $15.53^{\mathrm{ab}}$ & $46.61^{\mathrm{abc}}$ & $35.67^{\mathrm{ab}}$ & 15.2 \\
\hline T7 & $62.00^{c}$ & $72.00^{c}$ & $125.00^{c}$ & $99.00^{\mathrm{ab}}$ & $238.33^{a}$ & $14.20^{\mathrm{abc}}$ & $46.59^{a b c}$ & $32.70^{\mathrm{abc}}$ & 14.9 \\
\hline T8 & $62.00^{c}$ & $72.00^{c}$ & $125.00^{c}$ & $87.00^{b c}$ & $221.67^{a b c}$ & $13.933^{\mathrm{bcd}}$ & $43.32^{\mathrm{bcd}}$ & $31.43^{b c}$ & 15.4 \\
\hline T9 & $62.00^{c}$ & $72.00^{c}$ & $125.00^{c}$ & $88.33^{b c}$ & $219.00^{\mathrm{abcd}}$ & $13.36^{\text {cde }}$ & $48.85^{a}$ & $33.17^{a b c}$ & 15.1 \\
\hline T10 & $62.00^{c}$ & $72.00^{c}$ & $125.00^{c}$ & $113.67^{a}$ & $245.67^{a}$ & $16.10^{a}$ & $47.30^{\mathrm{ab}}$ & $37.10^{\mathrm{a}}$ & 15.1 \\
\hline LSD(0.01) & $3.13^{\star \star}$ & $3.13^{* *}$ & $3.13^{\star \star}$ & $16.869 * *$ & 32.667 ** & $2.04 * \star$ & $4.26^{\star \star}$ & $5.42^{\star \star}$ & - \\
\hline CV & 1.39 & 2.38 & 2.74 & 10.93 & 8.78 & 8.61 & 5.66 & 9.90 & 2.95 \\
\hline \multicolumn{10}{|c|}{ 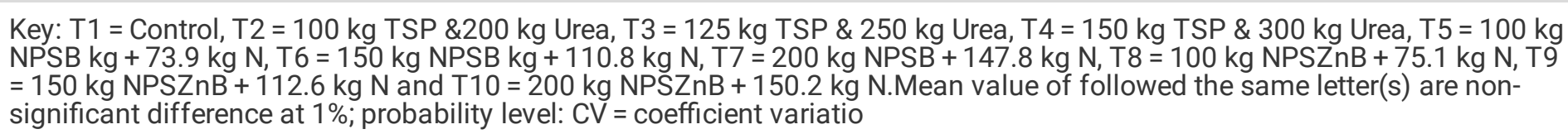 } \\
\hline
\end{tabular}

\section{Effects of blended fertilizer rates and types on maize grain and straw yields}

The analysis of variance for grain and straw yields revealed highly significant $(P \leq 0.01)$ difference among the treatments. However the two blended fertilizer types was not significantly different in affecting most parameters (Table 1). The two types of blended fertilizer had significantly improved grain yield, which might be attributed to the contribution of relatively more types of nutrients (N, P, S, B and Zn) supply in the blended fertilizer as compared to the recommended $\mathrm{N}$ and $\mathrm{P}$, and control. The low yield of maize under application of recommended $\mathrm{N}$ and $\mathrm{P}$ might be due to the absence of other macro and micro nutrients(S, $\mathrm{Zn}$ and B). Similar trend has been reported by (Boorboori et al., 2012).

Application of $200 \mathrm{~kg} \mathrm{NPSZnB}+150.2 \mathrm{~kg} \mathrm{~N} \mathrm{ha}^{-1}$ increased grain yield by $135.5 \%$ and $111.1 \%$ over control and $100 \%$ recommended NP, respectively. Similar trend has been observed by ${ }^{18}$ in wheat crop. Grain yield increment with application of 
blended fertilizers which contained S, B and Zn indicated that there is a need to supplement these elements for maize production. The increase in grain yield could be attributed to beneficial influence of yield contributing characters and positive interaction of nutrients in the blended fertilizer (Dagne 2016). The strong relationships were found between grain yield and ear length, grain yield and 100 kernels weight, and number of kernels per row.

The low yield in unfertilized plots might have been due to reduced leaf area development resulting in lesser radiation interception and, consequently, low efficiency in the conversion of solar radiation (Sallah et al.,1998).

The highest maize straw yield (7886.7 $\mathrm{kg} \mathrm{ha}^{-1}$ ) was recorded with $150 \mathrm{~kg} \mathrm{NPSB}+110.8 \mathrm{Nkg} \mathrm{ha}^{-1}$ application, while the lowest value (4400.9 $\mathrm{kg} \mathrm{ha}^{-1}$ ) was recorded with control treatment. Application of $150 \mathrm{~kg} \mathrm{NPSB}+110.8 \mathrm{~N} \mathrm{~kg} \mathrm{ha}^{-1}$ resulted in $79.21 \%$ and $54.0 \%$ more straw yield as compared to the control and recommended $\mathrm{N}$ and $\mathrm{P}$.

Table 2

Above ground biomass yield, grain yield, straw yield and harvest index of maize as influenced by blended fertilizer types and rates in Assosa district.

\begin{tabular}{|c|c|c|c|}
\hline Treatments & $\begin{array}{l}\text { Grain yield } \\
\left(\mathrm{kg} \mathrm{ha}^{-1}\right)\end{array}$ & Straw yield $\left(\mathrm{kg} \mathrm{ha}^{-1}\right)$ & Harvest index \\
\hline Control & $2996.0 \mathrm{e}$ & $4400.9 \mathrm{e}$ & $0.41 \mathrm{bcd}$ \\
\hline 100 kg TSP + 200 kg Urea & $3342.5 \mathrm{de}$ & 5119.8de & $0.40 \mathrm{~cd}$ \\
\hline 125 kg TSP + 250 kg Urea & 3569.3de & 5337.7de & $0.40 \mathrm{~cd}$ \\
\hline 150 kg TSP + 300 kg Urea & $3958.9 d$ & $5882.4 \mathrm{~cd}$ & $0.40 \mathrm{~cd}$ \\
\hline 100 kg NPSB + 73.9 kg N & $5789.8 b c$ & 6971.7ab & $0.46 a b$ \\
\hline 150 kg NPSB 110. +8 kg N & $6863.4 a$ & $7886.7 a$ & $0.47 a$ \\
\hline $200 \mathrm{~kg} \mathrm{NPSB}+147.8 \mathrm{~kg} \mathrm{~N}$ & $6563.8 a$ & 6971.7ab & $0.48 a$ \\
\hline 100 kg NPSZnB + $75.1 \mathrm{~kg} \mathrm{~N}$ & $5473.3 c$ & $6644.9 b c$ & $0.45 a b c$ \\
\hline 150 kg NPSZnB + 112.6 kg N & $6538.7 \mathrm{ab}$ & $7124.2 \mathrm{ab}$ & $0.48 a$ \\
\hline $200 \mathrm{~kg} \mathrm{NPSZnB}+150.2 \mathrm{~kg} \mathrm{~N}$ & $7056.2 a$ & $7559.9 a b$ & $0.49 a$ \\
\hline LSD (0.05) & $758.71^{\star \star}$ & $1065.4^{\star \star}$ & $0.05^{\star \star}$ \\
\hline CV (\%) & 8.48 & 9.72 & 6.95 \\
\hline
\end{tabular}

\section{Effects of blended fertilizer rates and types on maize harvest index}

The physiological ability of maize to convert total dry matter in to grain yield is determined by its harvest index (HI). The analysis of variance revealed that fertilizer rates and types had highly significantly $(P \leq 0.01)$ influenced harvest index of maize. However there were no significant differences between the two blended fertilizer types effect on HI of maize (Table 1). Both blended fertilizer types (NPSZnB and NPSZnB) gave more response to harvest index than recommended N and P and the control. Nevertheless, non-significant difference between recommended $\mathrm{N}$ and $\mathrm{P}$ and control was observed with regard to harvest index. The highest harvest index (0.49) was obtained at application of $200 \mathrm{~kg} \mathrm{NPSZnB}+150.2 \mathrm{~kg} \mathrm{~N}^{-1}$ while the lowest harvest index (0.40) was recorded under the recommended $\mathrm{N}$ and $\mathrm{P}$.

The increase in the harvest index due to application of micronutrients may be attributed to their role in enhancing the photosynthesis process and translocation of photosynthetic products to economic part. Generally application of blended 
fertilizers had significant effects on harvest index of maize crop than recommended $\mathrm{N}$ and $\mathrm{P}$. This result agrees with the findings of (Sallah et al.,1998) who reported that harvest index of tef was found to be highest in blended fertilizer treatments. This report was also slightly similar with (Tekle and Wassie 2018) those reported the harvest index of maize was found to be significantly higher in plots that received blended fertilizers at rate of $150 \mathrm{~kg} \mathrm{NPSZnB} \mathrm{ha}^{-1}$ as contrasted to the control treatment but, it was significantly in par with $300 \mathrm{~kg} \mathrm{NPSZnB} \mathrm{ha}^{-1}$ and recommended NP fertilizers.

\section{Physiological efficiency grain and apparent recovery of biological yield of maize}

The highest mean of apparent recoveries of $\mathrm{N}$ and $\mathrm{P}$ recorded were $28.05 \%$ and $14.70 \%$, respectively. The apparent $\mathrm{N}$ recovery decreased with increasing rate of blended fertilizer application (Table 3), however $\mathrm{P}$ recovery decreased with increasing rate of blended fertilizers were inconsistence. The maximum (28.05\%) and minimum (7.27\%) apparent recoveries of $\mathrm{N}$ were obtained at $100 \mathrm{~kg} \mathrm{NPSB}+73.9 \mathrm{~N} \mathrm{~kg} \mathrm{ha}^{-1}$ and $100 \mathrm{~kg}$ TSP \& $200 \mathrm{~kg} \mathrm{Urea} \mathrm{ha}^{-1}$, respectively. There was a decrease in the apparent recovery of fertilizer $\mathrm{N}$ at each successive increment of fertilizer so that the highest recovery always occurred at lowest increment of fertilizer (Doyle et al., 1993). Similarly the maximum (14.70\%) and minimum (0.92\%) apparent recoveries of $P$ were obtained at $100 \mathrm{~kg} \mathrm{NPSZnB}+75.1 \mathrm{~N} \mathrm{~kg} \mathrm{ha}{ }^{-1}$ and $100 \mathrm{~kg}$ TSP \& $200 \mathrm{~kg}$ Urea ha $^{-1}$, respectively (Table 4). The blended fertilizer had improved the $\mathrm{N}$ and $\mathrm{P}$ recovery over recommended $\mathrm{N}$ and $\mathrm{P}$ might be the contribution of macronutrient $(\mathrm{S})$ and micronutrient $(\mathrm{B}$ and $\mathrm{Zn})$ present in blended fertilizer increased the availability of macro nutrients. The $\mathrm{N}$ and $\mathrm{P}$ apparent recovery is in line with the findings of (Sandana, 2016) which indicate that the level and types of nutrient fertilization affects the nutrient availability in soil and at high contents of soil nutrients and their availability more nutrients might be taken up by plants. In general, fertilizer $\mathrm{N}$ recovery by rice is never too high due to various types of losses including denitrification, volatilization and leaching losses (Brady \& Weil, 2002).

Table 3

Mean of apparent recovery, physiological efficiency and agronomic use efficiency of maize.

\begin{tabular}{|c|c|c|c|c|c|}
\hline \multirow[t]{2}{*}{ Treatment (Nutrients ha ${ }^{-1}$ ) } & \multicolumn{2}{|l|}{ AR $\%$} & \multicolumn{2}{|c|}{$\mathrm{PE} \mathrm{Kg} \mathrm{kg}{ }^{-1}$} & \multirow[t]{2}{*}{ AUE kg kg-1 } \\
\hline & $\mathrm{P}$ & $\mathrm{N}$ & $P$ & $\mathrm{~N}$ & \\
\hline Control & - & - & - & - & - \\
\hline 100 Kg TSP\&200 Kg Urea & 0.92 & 7.27 & 818.60 & 51.77 & 2.51 \\
\hline 125 Kg TSP \& 250 Kg Urea & 1.84 & 8.03 & 540.51 & 62.09 & 3.30 \\
\hline 150 Kg TSP \& 300 Kg Urea & 3.23 & 9.63 & 431.92 & 72.44 & 4.70 \\
\hline $100 \mathrm{Kg}$ NPSB Kg + $73.9 \mathrm{~N}$ & 9.14 & 28.05 & 847.02 & 108.27 & 19.64 \\
\hline $150 \mathrm{Kg}$ NPSB Kg + 110.8N & 10.77 & 24.54 & 663.15 & 114.22 & 18.13 \\
\hline $200 \mathrm{Kg}$ NPSB Kg $+147.8 \mathrm{~N}$ & 7.73 & 17.02 & 639.54 & 113.94 & 12.54 \\
\hline $100 \mathrm{Kg} \mathrm{NPSZnB}+75.1 \mathrm{~N}$ & 14.70 & 25.43 & 498.74 & 105.90 & 16.94 \\
\hline 150 Kg NPSZnB + $112.6 \mathrm{~N}$ & 12.20 & 22.98 & 572.58 & 113.37 & 16.15 \\
\hline $200 \mathrm{Kg}$ NPSZnB + $150.2 \mathrm{~N}$ & 12.20 & 22.64 & 492.49 & 96.04 & 13.71 \\
\hline
\end{tabular}

The small number of grain and straw nutrient concentration and up take of P might be due to the P fixation by acidity, and Al toxicity of the experimental site. Low available P of these soils could be one of the major soil fertility limiting factors in the study area, which limit the nutrient use efficiency of experimental site as was also confirmed by soil characterization of the studied area. This result is line with (Kirsten, 2014), who found phosphorus availability to plants is determined by the chemical characteristics of the soil and the $P$ fertilizer source.

The physiological efficiency of $\mathrm{N}$ and $\mathrm{P}$ were influenced by the application of blended fertilizer rates, types and recommended $\mathrm{N}$ and $\mathrm{P}$ (Table 4). The highest (114.22 $\mathrm{kg} \mathrm{kg}^{-1}$ ) and lowest $\left(51.77 \mathrm{~kg} \mathrm{~kg}^{-1}\right)$ values of physiological efficiency of $\mathrm{N}$ were recorded at 
application rate of $150 \mathrm{~kg} \mathrm{NPSB}+110.8 \mathrm{~N} \mathrm{~kg} \mathrm{ha}^{-1}$ and $100 \mathrm{~kg}$ TSP \& $200 \mathrm{~kg}$ Urea ha ${ }^{-1}$, respectively. Cras well and Godwin (1984), explained physiological efficiency of crop and they found high physiological efficiency on $\mathrm{N}$ usage cereal achieved when high portion of $\mathrm{N}$ taken up is used for grain formation. Physiological $\mathrm{N}$ use efficiency (Singh, 1998) or $\mathrm{N}$ use efficiency for grain production (Borrell et al., 1998) refers to the additional yield produced for each additional $\mathrm{kg}$ of fertilizer $\mathrm{N}$ uptake and is determined as the ratio of net grain yield produced due to the applied fertilizer to the net uptake from applied fertilizer $\mathrm{N}$.

The highest $\left(847.02 \mathrm{~kg} \mathrm{~kg}^{-1}\right.$ ) physiological efficiency of $\mathrm{P}$ at a blended fertilizer rate of $100 \mathrm{~kg} \mathrm{NPSB} \mathrm{kg}+73.9 \mathrm{~N} \mathrm{~kg} \mathrm{ha}^{-1}$, mean while the lowest value of (431.92 $\mathrm{kg} \mathrm{kg}^{-1}$ ) was obtained at $150 \mathrm{~kg}$ TSP \& $300 \mathrm{~kg}_{\text {Urea ha-1 }}^{-1}$ (Table 18). According to (Dobermann 2005) the physiological efficiency values should commonly range between 30 to $60 \mathrm{~kg} \mathrm{~kg}^{-1}$. If the obtained results are above these common values, it could be concluded that the farm was under well managed system and the reverse is true, if the results obtained are below the common values. The physiological efficiency of the experimental site was above the common values for both $\mathrm{N}$ and $\mathrm{P}$ physiological efficiency. Generally the physiological efficiency of $\mathrm{P}$ was high as compared to $\mathrm{N}$ this might be due to relatively higher yield produced with low uptake of $\mathrm{P}$ as compared with $\mathrm{N}$ of uptake.

\section{Agronomic fertilizer use efficiency of maize grain}

Agronomic fertilizer use efficiencies of maize were influenced by blended fertilizer rates and recommended $\mathrm{N}$ and $\mathrm{P}$ (Table 3 ). The agronomic fertilizer use efficiency of maize was varied from 2.5 to $19.64 \mathrm{~kg} \mathrm{ha}^{-1}$ at harvest stage of maize. The highest agronomic fertilizer use efficiency $\left(19.64 \mathrm{~kg} \mathrm{~kg}^{-1}\right)$ was obtained under application of $100 \mathrm{~kg} \mathrm{NPSB}+73.9 \mathrm{~N}$, while minimum value of agronomic fertilizer use efficiency $\left(2.5 \mathrm{~kg} \mathrm{~kg}^{-1}\right)$ was recorded from $100 \%$ recommended $\mathrm{N}$ and $\mathrm{P}$. Therefore, it seems that recommended $\mathrm{N}$ and $\mathrm{P}$ could not be an adequate application level regarding nourishing of this hybrid maize, perhaps due to limitation in the numbers of essential nutrients applied.

Karim \& Ramasamy, (2000) Suggested that higher fertilizer use efficiency which is always associated with low fertilizer rate, cultural practices meant for promoting integrated nutrient management will help to effect saving in the amount of fertilizer applied to the crops and there to improve fertilizer use efficiency. Agronomic fertilizer use efficiency of any nutrient can be increased by increasing plant uptake and use of nutrient and by decreasing nutrient losses from the soil-plant system. The blended fertilizer applied improved agronomic fertilizer use efficiency by $682.47 \%$ as compared to recommended $\mathrm{N}$ and $\mathrm{P}$ fertilizers.

Mengel et al. (2006) agronomic fertilizer use efficiency value for a nutrient should not be less than 5 . This result therefore shows that the rates of recommended $\mathrm{N}$ and $\mathrm{P}$ of studied ranged from 2.51 to $4.7 \mathrm{~kg} \mathrm{~kg}^{-1}$ which is less than the minimum standard $A E$ according to (Mengel et al., 2006). Values of $A E$ were lower than 5 for recommended $\mathrm{N}$ and $\mathrm{P}$ that may be due to nutrient imbalance of recommended $\mathrm{N}$ and $\mathrm{P}$ and this indicates that higher rate of $\mathrm{N}$ and $\mathrm{P}$ were not well utilized though a limiting nutrient. On the other hand, the agronomic efficiency for blended fertilizer types and rates of studied area were within the optimum rage (12.54 to $19.64 \mathrm{~kg} \mathrm{~kg}^{-1}$ ). This result is similar with (Dobermann, 2005) who reported that agronomic fertilizer use efficiency should be within the ranges of 10 to $30 \mathrm{~kg} \mathrm{~kg}^{-1}$.

\section{Partial Budget Analysis}

The net benefit curve is allows to mark out an efficient set of technologies for recommendation. The application of $150 \mathrm{~kg}$ NPSB $+110.8 \mathrm{~N} \mathrm{~kg} \mathrm{ha}^{-1}$ had the highest net-benefit of 32321.4 ETB, followed by $200 \mathrm{~kg} \mathrm{NPSZnB}+150.2 \mathrm{~N}, 150 \mathrm{~kg} \mathrm{NPSZnB}+112.6 \mathrm{~N}$, $200 \mathrm{~kg} \mathrm{NPSB}+147.8 \mathrm{~N}$ and $100 \mathrm{~kg}$ NPSB $+73.9 \mathrm{~N} \mathrm{~kg} \mathrm{ha}^{-1}$ which also had a total of 31,845.6, 30,478.1, 29,430.5 and 27,945.7 ETB net benefit respectively. The lowest net benefit was obtained by the application of the $100 \%$ recommended $N$ and P with total of 14,891 ETB followed by $125 \%$ recommended nitrogen and phosphorous and control with net benefit of $15,528.5$ and 16,080 ETB the respectively. Furthermore $150 \%$ recommended nitrogen and phosphorous also had lower net benefit of $16,595.5 \mathrm{ETB}$. The increased production of the crop due to the application of inputs might or might not be beneficiary to farmers (CIMMYT, 1988). Therefore, partial budget analysis (CIMMYT, 1988) was employed to estimate the net benefit, dominance analysis and marginal rate of return that could be obtained from various alternative treatments (CIMMYT, 1988). The profitability of the study showed that application of $150 \mathrm{~kg} \mathrm{NPSB}+110.8 \mathrm{~N} \mathrm{~kg} \mathrm{ha}^{-1}$ and $150 \mathrm{~kg} \mathrm{NPSZnB}+112.6 \mathrm{~N} \mathrm{~kg} \mathrm{ha}^{-1}$ which provided the relatively high net benefit (32,321.4 and 30,478.1ETB) respectively, was the peak to apply fertilizers. The total costs that vary 
increased over the optimum level, the net benefit obtained reduced as the result of higher variable costs associated with lower earnings.

Table 4

Partial Budget Analysis of blended fertilizer application rates and types on maize at Asossa Zone

\begin{tabular}{|c|c|c|c|c|c|c|c|}
\hline \multirow[t]{2}{*}{ Treatments } & \multirow{2}{*}{$\begin{array}{l}\text { VC } \\
\text { (ETB ha' }\end{array}$} & \multicolumn{2}{|c|}{ Yield kg ha-1 } & \multicolumn{2}{|c|}{ GR (ETB ha $\left.{ }^{-1}\right)$ from } & \multirow[t]{2}{*}{ TGR $\left(\right.$ ETBha $\left.^{-1}\right)$} & \multirow[t]{2}{*}{ NB $\left(\right.$ ETBha $\left.^{-1}\right)$} \\
\hline & & Straw & Grain & Straw & Grain & & \\
\hline T1 & 0 & 4400 & 2996 & 1100 & 14980 & 16080 & 16080 \\
\hline T2 & 3,073 & 5019 & 3342 & 1254 & 16710 & 17964 & 14891 \\
\hline T3 & 3622.5 & 5227 & 3569 & 1306 & 17845 & 19151 & 15528.5 \\
\hline T4 & 4639.5 & 5762 & 3959 & 1440 & 19795 & 21235 & 16595.5 \\
\hline T5 & 2721.3 & 6870 & 5790 & 1717 & 28950 & 30667 & 27945.7 \\
\hline T6 & 3937.6 & 7776 & 6863 & 1944 & 34315 & 36259 & 32321.4 \\
\hline T7 & 5106.5 & 6871 & 6564 & 17178 & 32820 & 34537 & 29430.5 \\
\hline T8 & 2825.6 & 6524 & 5473 & 1631 & 27365 & 28996 & 26170.4 \\
\hline T9 & 3971.9 & 7020 & 6539 & 1755 & 32695 & 34450 & 30478.1 \\
\hline T10 & 5293.4 & 7439 & 7056 & 1859 & 35280 & 37139 & 31845.6 \\
\hline
\end{tabular}

\section{Dominance analysis}

The highest net benefits from the application of inputs for the production of the crop might not be sufficient for the farmers to accept as good practices. In most cases, farmers prefer the highest profit (with low cost and high income). For this purpose it is necessary to conduct dominated treatment analysis (CIMMYT, 1988). The \% MRR between any pair of undominated treatments denotes the return per unit of investment in fertilizer expressed as a percentage. A dominated treatment is any treatment that has net benefits that are less than those of a treatment with lower costs that vary (Stephen and Nicky, 2007). 
Table 5

Dominance analysis of blended fertilizer and recommended N and P application in Asossa district during 2016/17.

\begin{tabular}{|c|c|c|c|c|}
\hline Treatments (Nutrient ha-1) & VC(ETB ha-1) & NB(ETB ha-1) & MRR\% & $\mathrm{B}: \mathrm{C}$ ratio \\
\hline Control & 0 & 16080 & 0 & 0 \\
\hline $100 \mathrm{Kg} \mathrm{NPSB}+73.9 \mathrm{~N}$ & 2721.3 & 27945.7 & 436.0 & 10.3 \\
\hline $100 \mathrm{Kg}$ NPSZnB + 75.1 N & 2825.6 & 26170.4 & $\mathrm{D}$ & 9.3 \\
\hline 100 Kg TSP\& 200 Kg Urea & 3,073 & 14891.0 & $\mathrm{D}$ & 4.8 \\
\hline 125 Kg TSP \& 250 Kg Urea & 3622.5 & 15528.5 & $\mathrm{D}$ & 4.3 \\
\hline $150 \mathrm{Kg} \mathrm{NPSB}+110.8 \mathrm{~N}$ & 3937.6 & 32321.4 & 5329.4 & 8.2 \\
\hline $150 \mathrm{Kg} \mathrm{NPSZnB}+112.6 \mathrm{~N}$ & 3971.9 & 30478.1 & D & 7.7 \\
\hline 150 Kg TSP \& 300 Kg Urea & 4639.5 & 16595.5 & D & 3.6 \\
\hline $200 \mathrm{Kg} \mathrm{NPSB}+147.8 \mathrm{~N}$ & 5106.5 & 29430.5 & D & 5.8 \\
\hline $200 \mathrm{Kg}$ NPSZnB + $150.2 \mathrm{~N}$ & 5293.4 & 31845.6 & D & 6.0 \\
\hline
\end{tabular}

The dominance analysis showed that the net benefit of all treatments were dominated except application of $100 \mathrm{~kg}$ NPSB +73.9 $\mathrm{N} \mathrm{kg} \mathrm{ha}{ }^{-1}$ and $150 \mathrm{~kg} \mathrm{NPSB}+110.8 \mathrm{~N} \mathrm{~kg} \mathrm{ha}^{-1}$ (Table 5). This result indicated that the net benefit was decreased as the total cost that varies increased beyond undominated fertilizer treatments application. Therefore, no farmer may choose other dominated treatments in comparison with the undominated treatments. This also helps to avoid the dominated treatment in further estimate of marginal rates of return.

\section{Marginal rate of return}

Economic analysis revealed that maximum marginal rate of return was recorded with application of $150 \mathrm{~kg}$ NPSB $+110.8 \mathrm{~N} \mathrm{~kg}$ $\mathrm{ha}^{-1}(5329.4 \%)$, followed by $100 \mathrm{~kg} \mathrm{NPSB}+73.9 \mathrm{~N} \mathrm{~kg} \mathrm{ha}^{-1}(436.0 \%)$. The marginal rates of those treatments were well above the 100\% minimum (CIMMYT, 1988). According to (CIMMYT, 1988) experience and empirical evidence, for the majority of situations indicated that the minimum rate of return acceptable to farmers would be between 50 and $100 \%$. In the present study the treatments that had above $100 \%$ marginal rate return was recommended for the farmers, with treatments that had small number of variable cost. This treatment was $150 \mathrm{~kg} \mathrm{NPSB}+110.8 \mathrm{~N} \mathrm{~kg} \mathrm{ha}^{-1}$.

Table 6

Marginal rate of return analysis of blended fertilizer and recommended $\mathrm{N}$ and P application for maize in Asossa district during 2016/17.

\begin{tabular}{|c|c|c|c|}
\hline Treatments (Nutrient ha ${ }^{-1}$ ) & VC(ETB ha-1) & NB(ETB ha-1) & MRR\% \\
\hline Control & 0 & 16080 & 0 \\
\hline $100 \mathrm{Kg} \mathrm{NPSB}+73.9 \mathrm{~N}$ & 2721.3 & 27945.7 & 436.0 \\
\hline $150 \mathrm{Kg} \mathrm{NPSB}+110.8 \mathrm{~N}$ & 3937.6 & 32321.4 & 5329.4 \\
\hline
\end{tabular}

The \% MRR between any pair of undominated treatments denotes the return per unit of investment in fertilizer expressed as a percentage. The results of undominated treatments indicated that for each one birr invested in purchase or production of fertilizers that was possible to recover one birr plus an extra of 4.36 birr ha $^{-1}$ and 53.29 birr ha $^{-1}$ as the fertilizer application changed from unfertilized plot to $100 \mathrm{~kg} \mathrm{NPSB}+73.9 \mathrm{~N} \mathrm{~kg} \mathrm{ha}^{-1}$ and $150 \mathrm{~kg} \mathrm{NPSB}+110.8 \mathrm{~N} \mathrm{~kg} \mathrm{ha}^{-1}$ respectively. Passing from the first treatment that had the lowest costs that vary to the end treatment which had the highest cost that vary, the marginal rate of return obtained was above the minimum acceptable marginal rate of return. 
In this study, $100 \%$ was considered as minimum acceptable rate of return for farmers $\Downarrow$ recommendation. Accordingly, the study revealed that application of $150 \mathrm{~kg} \mathrm{NPSB}+110.8 \mathrm{~N} \mathrm{~kg} \mathrm{ha}^{-1}$ was considered as the best for recommendation. The best recommendation for treatments subjected to marginal rate of return is not necessarily based on the highest marginal rate of return, rather based on the minimum acceptable marginal rate of return and the treatment with the highest net benefit, relatively low variable cost together with an acceptable MRR becomes the tentative recommendation (CIMMYT, 1988).

\section{Conclusion}

The fertilizer rates and types on grain yield and straw yield highly significant difference $(P \leq 0.01)$, however there was no significant differences between the two blended fertilizer types. Maximum grain yield $7056.2 \mathrm{~kg} \mathrm{ha}^{-1}$ was recorded with T10 $(200 \mathrm{~kg} \mathrm{NPSZnB}+150.2 \mathrm{~N})$, while minimum grain yield $2996.0 \mathrm{~kg} \mathrm{ha}^{-1}$ was recorded from control treatment. This maximum grain yield was followed by T6, T7 and T9 with corresponding grain yield of $6863.4,6563.8$ and $6538.7 \mathrm{~kg} \mathrm{ha}^{-1}$ respectively, where these treatments were statistically at par with each other. The maximum maize straw was recorded with T6 (7886.7 kg $\mathrm{ha}^{-1}$ ), while minimum value ( $4400.9 \mathrm{~kg} \mathrm{ha}^{-1}$ ) was recorded with control treatment. Accordingly, the study revealed that application of $150 \mathrm{~kg} \mathrm{NPSB}+110.8 \mathrm{~N} \mathrm{~kg} \mathrm{ha}^{-1}$ and $150 \mathrm{~kg} \mathrm{NPSZnB}+112.6 \mathrm{~N} \mathrm{~kg} \mathrm{ha}^{-1}$ as the best rates recommended for maize production at Assosa area.

Blended fertilizer had improved nutrient concentration, uptake, agronomic efficiency, physiological efficiency and apparent recovery of maize as compared to recommended $\mathrm{N}$ and $\mathrm{P}$. The improvements of uptake and nutrient use efficiency of maize by blended fertilizer might be due to the contribution of macro and micro nutrients present in blended fertilizer. Improving nutrient efficiency is an appropriate goal for all involved in agriculture, and the fertilizer industry, with the help of agronomic studies at different agro-ecologies. However, effectiveness cannot be sacrificed for the sake of efficiency. Much higher nutrient efficiencies could be achieved simply by sacrificing yield, but that would not be economically effective or viable for the farmer, or the environment. The profitability of the study showed that application of $150 \mathrm{~kg} \mathrm{NPSB} \mathrm{kg}+110.8 \mathrm{~N}$ and $150 \mathrm{~kg} \mathrm{NPSZnB}+112.6 \mathrm{~N}$ $\mathrm{kg}$ which provided relatively high net benefit (32321.4 and 30,478.1ETB) was the best rates to apply. Marginal rate of analysis from undominated treatments indicated that for each one birr invested in purchase or production of fertilizers that was possible to recover one birr plus an extra of 4.36 birr ha $^{-1}$ and 53.29 birr ha $^{-1}$ as the fertilizer application changed from unfertilized plot to $100 \mathrm{~kg} \mathrm{NPSB}+73.9 \mathrm{~N} \mathrm{~kg} \mathrm{ha}^{-1}$ and $150 \mathrm{~kg} \mathrm{NPSB}+110.8 \mathrm{~N} \mathrm{~kg} \mathrm{ha}^{-1}$ respectively.

The best recommendation for treatments subjected to marginal rate of return is not necessarily based on the highest marginal rate of return, rather based on the minimum acceptable marginal rate of return and the treatment with the high net benefit, relatively low variable cost together with an acceptable MRR becomes the tentative recommendation. Therefore we recommend the treatments $\left(150 \mathrm{~kg} \mathrm{NPSB}+110.8 \mathrm{~N} \mathrm{~kg} \mathrm{ha}^{-1}\right)$ that have high marginal rate of return, high net benefit and relatively small total cost of production for maize production in Asossa zone. But based on yield data, net benefit and relatively small total cost of production the farmer of Asossa district can also use $150 \mathrm{~kg} \mathrm{NPSZnB}+112.6 \mathrm{~N}$ when NPSB formula were not available on the market.

\section{Declarations}

\section{Funding}

Ethiopia Institutes of Agricultural Research had funded only the study design, data collection and analysis budget. That means the do no supporting the charge of the publication of the manuscript.

\section{Availability of data and materials}

Supporting data for the results have reported in this article can be found in progress and annual research review reports in Ethiopian Institute of Agricultural Research.

\section{Ethics approval and consent to participate}


All procedures performed in our study did not involved human participants, human data or human tissue.

\section{Consent for publication}

We understand that the text and any pictures or videos published in the article will be freely available on the internet and may be seen by the general public.

\section{Competing interests}

The authors declare that they have no competing interests.

\section{Acknowledgement}

The authors dully acknowledge the financial support of Ethiopian Institute of Agricultural Research for funding the first author to pursue his MSc study and for undertaking of this piece of field research to fulfill his MSc requirement.

\section{Author contribution}

Bakala Anbessa, Designed the study, performed the statistical analysis, wrote the protocol, and wrote the first draft of the manuscript. Dr. Girma Abera, edited and managed the analyses of the study and Dr. Sofiya Kassa edited and managed the analyses of the study.

\section{References}

[1].Bationo, A., T. Fairhurst, K. Giller, V. Kelly, R. Lunduka, A. Mando, Z. Shamie, 2012. Handbook for Integrated Soil Fertility Management.Africa Soil Health Consortium Fairhurst,., CAB International 2012.

[2].Boorboori, D.,A.MEradatmand\&J.Tehrani, 2012. Advances in Environmental Biology., 6,2, 740.

[3].Borrell, A.K., A. L Graside, S. Fukai, \& D J Reid, 1998. Plant type affect nitrogen uptake and nitrogen use efficiency in rice. Aust. J. Agric Res. 49:829-843

[4].Brady N.C\& R.R. Weil, 2002 .The nature and properties of soil, 13th Ed. Preason Education, Asia. 960p.

[5]. Chapman HD.,1965. Cation exchange capacity.In:C.A.Black,L.E. Ensminger and F,E Clerk (Eds). Methods of soil analysis. American society of Agronomy, 9: 891-901.

[6]. CIMMYT (International Maize and Wheat Improvement Center), 1988. From Agronomic Data to Farmer Recommendations: An Economics Training Manual.

[7]. Cras well ET, DC. Godwin,1984. The efficiency of nitrogen fertilizers applied to cereals in different climates. In: Tinker B, Launch A. (Eds.), Advance in Plant Nutrition, vol.1 Preager, New York. pp. 1-55.

[8]. CSA Central Statistical Agency., 2015/16. Agricultural Sample Survey Report on area and production of major crops, 1, Addis Ababa.

[9]. Dagne C., 2016.Blended Fertilizers Effects on Maize Yield and Yield Components of Western Oromia, Ethiopia.Agriculture, Forestry and Fisheries. Vol. 5, No. 5, 2016, pp. 151-162. doi: 10.11648/j.aff.20160505.13

[10]. Dobermann, A.R., 2005. "Nitrogen Use Efficiency - State of the Art. Agronomy \& horticulturefacultypublications.Paper316.http://digitalcommons.unl.edu/agronomyfacpub/316.

[11]. Dobermann, A.R., 2005. "Nitrogen Use Efficiency - State of the Art. Agronomy \& horticulturefacultypublications.Paper316.http://digitalcommons.unl.edu/agronomyfacpub/316. 
[12]. Doyle, A.D. \& I.C.R., Holford, 1993. The uptake of nitrogen by wheat, its agronomic efficiency and their relation ship to soil and fertilizer. J. Agric. Res. 44: 1245-58.

[13]. Fageria NK (2009). The use of nutrients in crop plants. Taylor and Francis Group, LLC CRC Press.

[14]. Fageria, N. K., V. C. Baligar \& R. B. Clark 2002. Micronutrients in crop production. Adv. Agron. J. 77: 185-268.

[15]. Fageria, N.K., V.C. Baligar, \& C.A. Jones, 2011. Growth and Mineral Nutrition of Field Crops 3 Edition., Taylor \& Francis Group. Available at: http://www.crcpress.com, (Accessed on August 2015).

[16]. GetacheA., A. Dejene., E.Zewdu and I. Fisseha. 2013.The state of science and technology in soil fertility and plant nutrient management research in Ethiopia.Conference: The State of Agricultural Science and Technology in Ethiopia. pp. 373- 412. In: BerhaneGebrekidan, SemeDebela, Solomon Bekure, TayeBezuneh, Solomon Hailemariam and GeteZeleke (eds.) 28-30 Nov. 2011, Ethiopian Academy of Sciences. ISBN978-99944-882-1-6. At: Addis Ababa, Ethiopia

[17]. Hagos K, Y. Haddis, T. Ykaalo, T Zebrhe and J. Jemal, 2016, Pre-extension Popularization of Improved Maize Varieties: In Raya-AzeboWoreda South of Tigray, Ethiopia. Journal of Economics and Sustainable Development, ISSN 2222-1700 (Paper) ISSN 2222-2855 (Online) Vol.7, No.9, 2016.

[18]. Hati, K.M., K.G. Mandal, A.K., Misra, P.K. Ghosh, and K.K., Bandyopadhyay, 2006. Effect of inorganic fertilizer and farmyard manure on soil physical properties, root distribution, and water-use efficiency of soybean in Vertisols of central India. Bioresource Technology 97(2): 2182-2188.

[19]. Karim, A.A., \& C.Ramasamy, 2000. Expanding frontiers of agriculture: contemporary issues. Kalyani Publishers, Ludhiana, India.

[20]. Kirsten A., 2014. The Agronomy Guide: Penn State College of Agricultural Sciences. , pp.41-58.

[21]. Landon J. R., 1991.Booker Tropical soil manual, a hand book for soil survey and agricultural land evaluation in the tropics and subtropics. Longman, Booker. 474p.

[22]. Mengel, K., C.A. Kirkby, H. Kosegarten \& T. Appel, 2006. Principles of Plant Nutrition. 5th Edn., Springer Publishers, New York, ISBN-13: 9781402000089 , Pages: 849.

[23]. Rasheed, M., H.Ali and T.Mahmood, 2004.Impact of nitrogen and sulfur application on growth and yield of maize (Zea mays L.) crop. J. Res. Sci., 15: 153-157.

[24]. Ryan, J., 2008. A Perspective on Balanced Fertilization in the Mediterranean Region. Turky journal of Agriculture, $32:$ 79-89.

[25]. Sallah, P. Y., N. J. Ehlke\&J. L.Geadelmann, 1998. Progress from Selection in Maize Population Evaluated Under Three Nitrogen Fertiliser Levels. African J. Crop Sci. 6: 241-248.

[26]. Sandana, P., 2016. Phosphorus Uptake and Utilization Efficiency in Response to Potato Genotype and Phosphorus Availability Mean temperature $\left({ }^{\circ} \mathrm{C}\right.$ ) Precipitation ( $\mathrm{mm}$ ) Mon ths. European Journal of Agronomy j, 76, pp.95-106.

[27]. SAS (Statistical Analysis system) Institute Inc.,1998, SAS Campus Drive, Cary, NorthCarolina 27513.

[28]. Singh U I, J. K.,E. C. Ladha, G.Castillo, A.Panzalon, Tirol-Padre \& M. Dugueq., 1998. Genetyphic variation in nitrogen use efficiency in medium and long duration rice. Field Crops Res. 58: 35-53.

[29]. Singh U I, J. K.,E. C. Ladha, G.Castillo, A.Panzalon, Tirol-Padre \& M. Dugueq., 1998. Genetyphic variation in nitrogen use efficiency in medium and long duration rice. Field Crops Res. 58: 35-53.

[30]. Stephen, K. \& M.Nicky, 2007. In-Service training on partial budgeting techniques. Mount Makulu, Lusaka, Zambia. 
[31]. TekleL., and H. Wassie (2018). Response of tef (Eragrostistef (Zucc.) Trotter) to blended fertilizers in Tembaro, Southern Ethiopia. Journal of Biology, Agriculture and Healthcare 8(13):34-39.

\section{Figures}

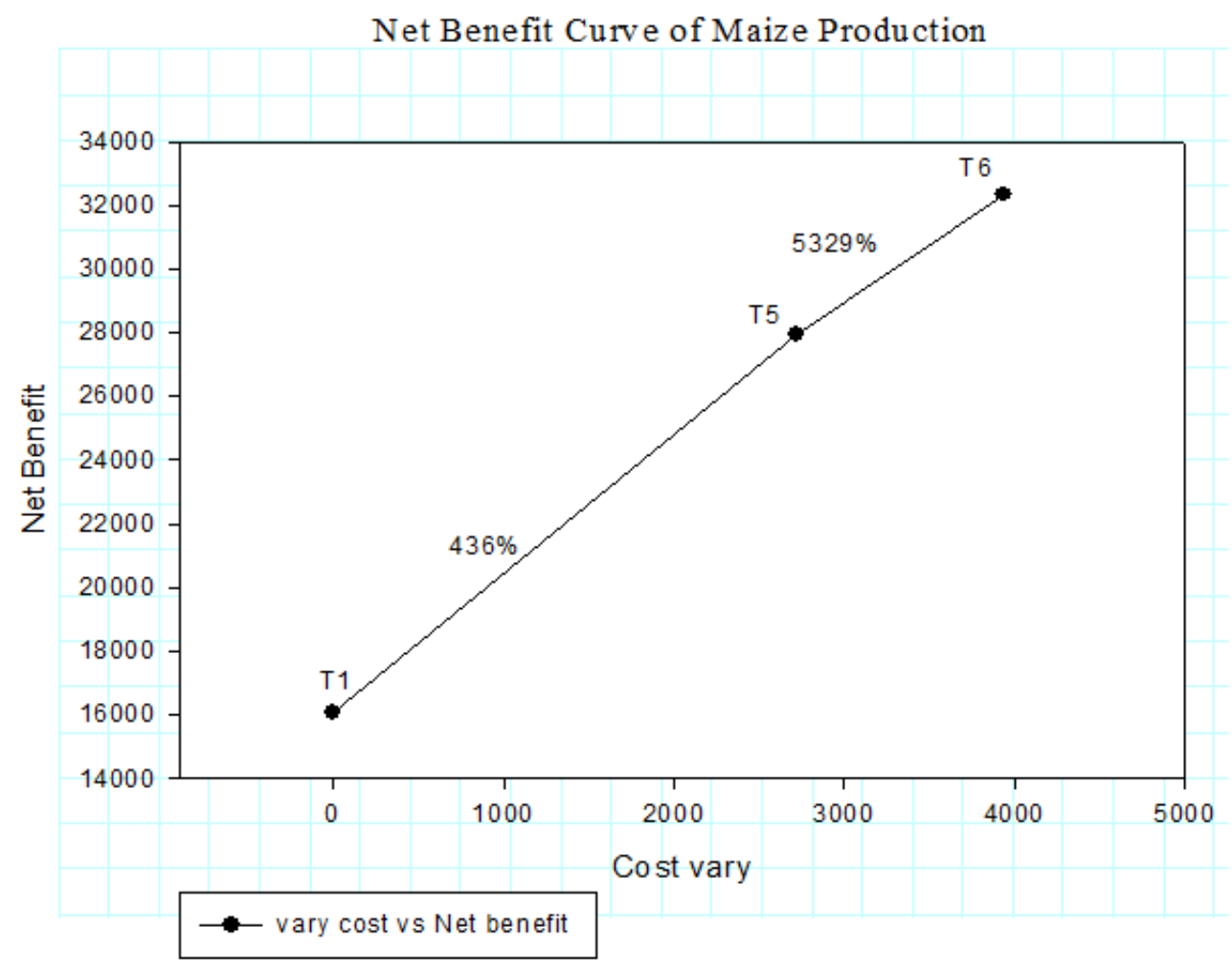

\section{Figure 1}

Net benefit curve of maize as influenced by blended fertilizer types and rates in Asossa district 